\title{
Chromosome-Associated Kinesin KIF4A Protein
}

National Cancer Institute

\section{Source}

National Cancer Institute. Chromosome-Associated Kinesin KIF4A Protein. NCI

Thesaurus. Code C63508.

Chromosome-associated kinesin KIF4A protein (1232 aa, 140 kDa) is encoded by the human KIF4A gene. This protein plays a role in mitosis, and is thought to play a role in tumor formation. 